\title{
SOIL LOSS ESTIMATION THROUGH USLE AND MMF METHODS IN THE LATERITIC TRACTS OF EASTERN PLATEAU FRINGE OF RAJMAHAL TRAPS, INDIA *GHOSH, S. and GUCHHAIT, S.K. \\ http://dx.doi.org/10.4314/ejesm.v5i4.S13
}

Received 8th September 2012; accepted 13th October 2012

\begin{abstract}
Laterites of Birbhum district are indentified as the 'low-level laterites' of 'Rarh Plain' of West Bengal and these are very much prone to severe soil erosion (mainly surface and sub-surface water erosion) in the monsoon season (June - September). Laterites and lateritic soils (locally named 'Kankara') of Caniozoic upland (adjoining areas of Rampurhat I block, Birbhum and Shikaripara block, Dumka- the study area), are the direct result of monsoonal wet-dry type of morpho-climatic processes and further laterisation of fluvial deposited materials (formation of surface duricrust) which was coming from Rajmahal Hills of eastern Chotanagpur Plateau (Jharkhand) in late Pleistocene. Such type of vermiform laterites is shaped and dissected by numerous gullies and ravines, giving birth of badland topography (locally named 'Khoai') of both degradation and aggradation processes. Before the soil conservation practices it is helpful if the assessment of soil erosion can be transformed into a statement of how fast soil is being eroded. The estimation of rate of annual soil loss is required in that case, because we must have to predict soil loss through effective models under a wide range of conditions. In this study the entire assessment is focused on the application Universal Soil Loss Equation (USLE) and Morgan, Morgan and Finney (MMF) methods in the soil loss estimation of sample slope segments, and relative comparison and suitability of both methods in the precise estimation of predicting soil loss.
\end{abstract}

Key words: Laterite, Gully, Rainsplash, Overland flow, USLE and MMF

\section{Introduction}

Laterites of tropical climate are highly weathered material, rich in secondary oxides of iron, aluminum, or both and are usually reddish brown, have moderate density $2.5-$ $3.6 \mathrm{gm} / \mathrm{cm}^{3}$; may contain large amounts of quartz and kaolinite but low in the other forms of silica; exchangeable bases and humus are absent (McFarlane, 1976; Raychaudhury, 1980). The name 'laterite' was given by $F$. Bhuchanan (1807) to describe the hard ferruginous deposits of Kerala. Raychaudhury (1980) has cast light on the different forms of laterite in India. Wadia (1945) classified laterite as high-level laterite normally found at an elevation of more than 2000 metre and lowlevel laterite below 2000 metre. High-level is undoubtedly massive and relatively hard whereas low-level laterite is nodular, detritus and soft (Raychaudhury, 1980). Laterites of West Bengal are regarded as the low-level laterites of 'Rarh Plain' of West Bengal where the underlying lithomergic clay is more prone

${ }^{1}$ Post Graduate Department of Geography

The University of Burdwan, West Bengal.

*Corresponding author: sandipanghosh19@gmail.com to gully and tunnel erosion (Bagchi and Mukherjee, 1983; Sarkar et al., 2007).

The contribution of Horton (1945) is considered as the fundamental threshold of geomorphic dynamics (Cooke and Droonkamp, 1987). As the important studies done by Ahmad (1968, 1973), Sharma (1970, 1980, 1986, 2009), Singh and Agnihotri (1987), Kale et al. (1994), Singh and Dubey (2002), S. Bandhyopadhyay et al. (1995, 2004), Jha and Kapat (2003, 2009, 2011) the gullies and ravines of India are generated in different types of soils through various stages under the influence of various factors (viz. neo-tectonic causes in peninsular margin of India, rejuvenation due to Quaternary climate change, land use and land cover change etc.). But on the low-level laterites of West Bengal the initiation, rejuvenation, progressive expansion of rills and gullies and factors of soil erosion is still unexplored and quantitatively measured.

The present investigation is concerned with the assessment of soil loss in the lateritic 529 
interfluve of River Brahmani and Dwarka, very close to Rajmahal Trap, where the samples have been chosen from different slope segments of the gully catchments. Soil erosion under fluvial action in the context of denudational dynamics is of critical importance where channel morphology and pedogeomorphic process are carefully observed in the investigation.

The chief objectives of this pedogeomorphic study are as follow:

1. To find out the environmental setting and morphogenetic processes of this area;

2. To perceive the erodibility of soil and bareness of land;

3. Predicting annual soil loss of eight sample sites using USLE and MMF models; and

4. Comparing the suitability and preciseness of the MMF model over USLE model in this area.

\section{Methodology}

Study Area - Physical Characteristics

The selected region of present study (area of $65.84 \mathrm{~km}^{2}$ ) is situated in the adjoining area of western Rampurhat I block of Birbhum district, West Bengal and eastern Shikaripara block of Dumka district, Jharkhand. It is the lateritic interfluve upland in between Brahmani (north) and Dwarka (south) rivers. The study area is located at $5 \mathrm{~km}$ west of Rampurhat railway station, near Baramasia bus-stop. The latitudinal extension ranges from $24^{0} 10^{\prime}$ to $24^{0} 13^{\prime} \mathrm{N}$, and longitudinal extension ranges from $87^{0} 39^{\prime}$ to $87^{0} 45^{\prime} \mathrm{E}$ (figures 2 and 3 ). The maximum and minimum altitudes are 89 metre and 36 metre from mean sea level respectively.
The study area is the small parts of old mature delta or 'Rarh Plain' of West Bengal, except the western margin of Rajmahal Basalt Trap. The laterite and lateritic soils of Cainozoic Era is found over Rajmahal TrapBasalt of Jurassic to Cretaceous Period. In some parts, the hard clays impregnated with caliche nodules (Rampurhat Formation) of late Pleistocene to early Holocene Epoch are found (Hundy and Banerjee, 1967).

Following the classification of Young (1976), the laterite of the plateau fringe areas of Chotanagpur (figure 2), adjacent to Rarh Plain can be classified into three groups (Young, 1976; Raychaudhuri, 1980):

(a) Hard ferruginized rock over the basaltic trap of Rajmahal;

(b) Nodular laterite of the slopping areas of plateau fringe; and

(c) Mottled iron rich soft laterite of the gullies.

In this monsoon climate, the seasonal fluctuations of temperature and humidity (annual rainfall of $1437 \mathrm{~mm}$ ) have a great impact on the laterisation and deep weathering processes (Bagchi and Mukherjee, 1983). The dry season (December-May) prepares the ground for land sculpturing. In this period, mechanical weathering of lateritic duricrust disintegrates into the loose surface materials which are ultimately washed out at onsets of occasional thunderstorms (locally called 'Kalbaisakhi', occurred in between MayJune). The severe erosion starts from the middle of June at the onset of monsoon rains which have mean intensity of 21.51 to 25.55 $\mathrm{mm}$ per hour. 

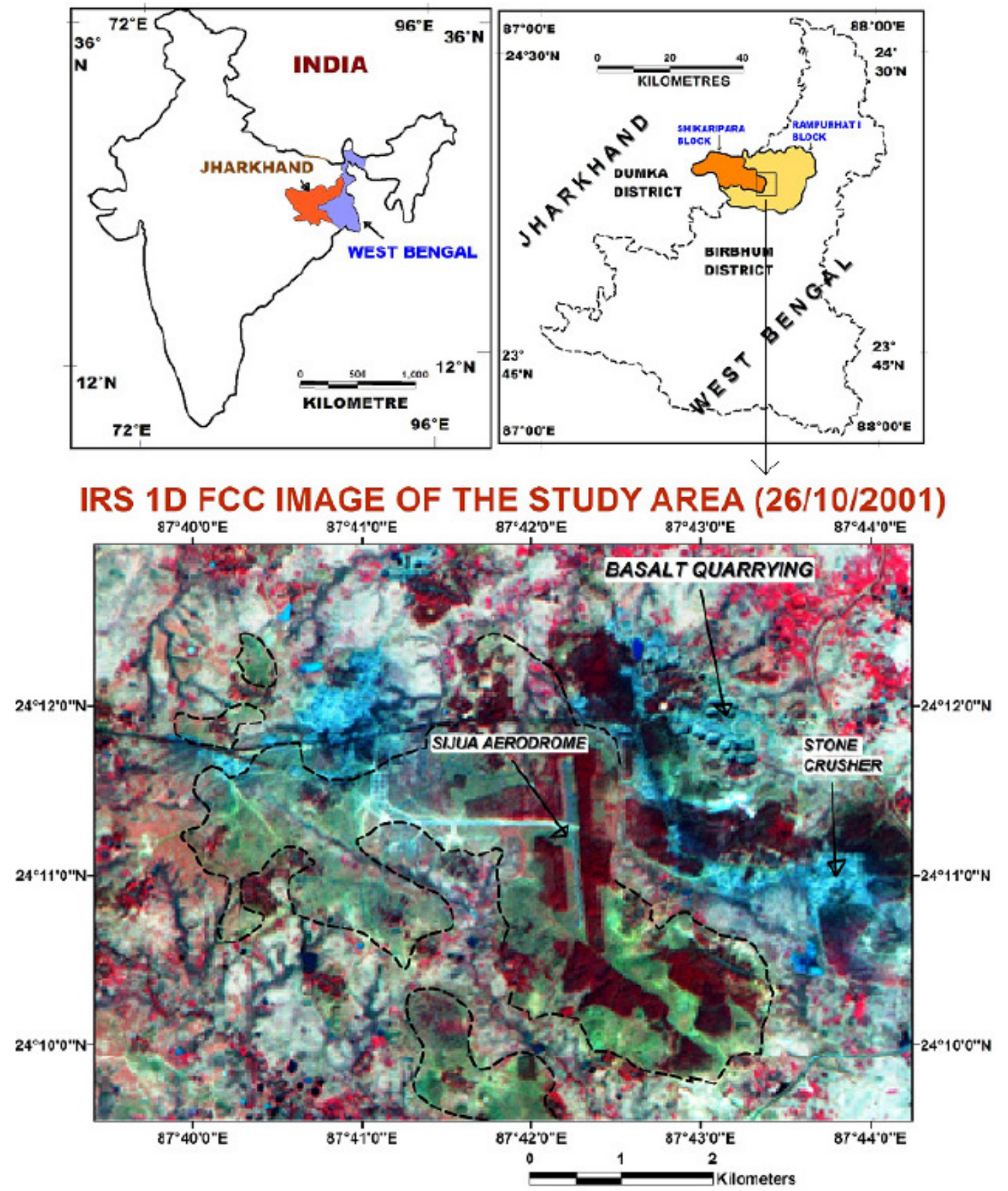

Figure 1: Location map of the study area 


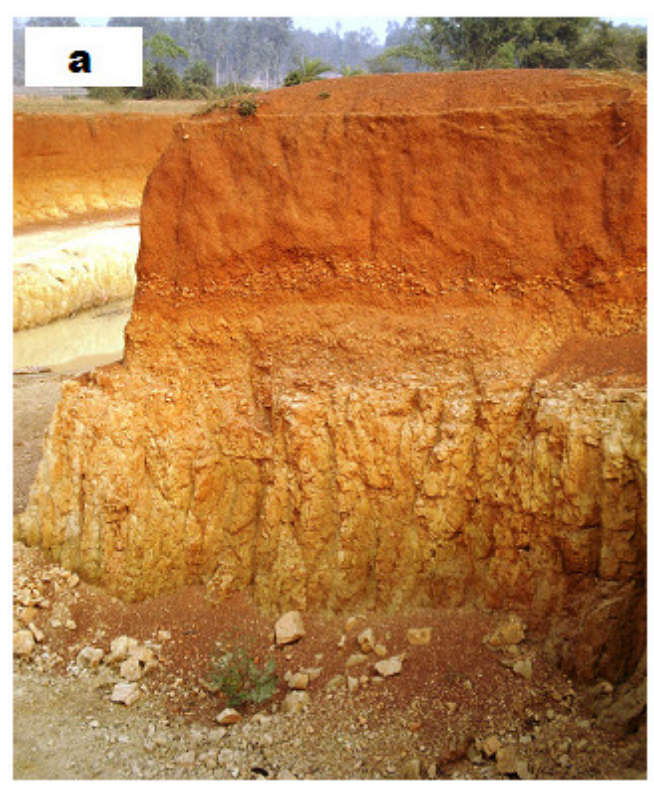

b

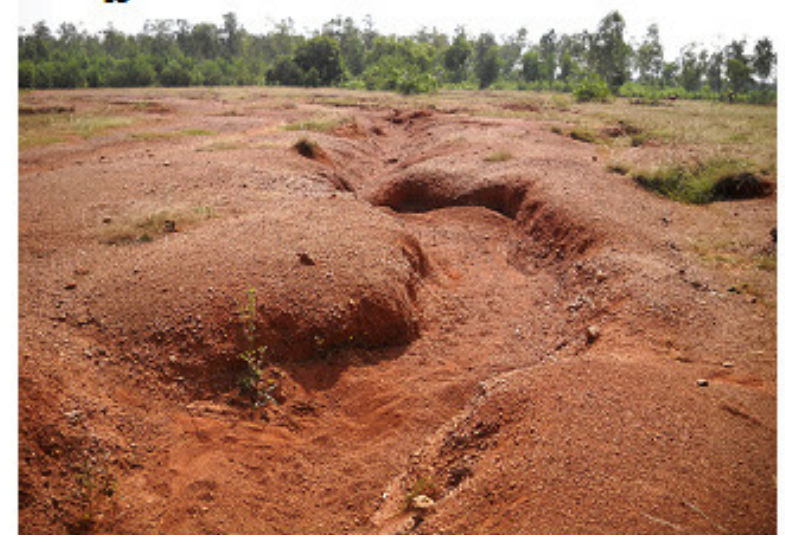

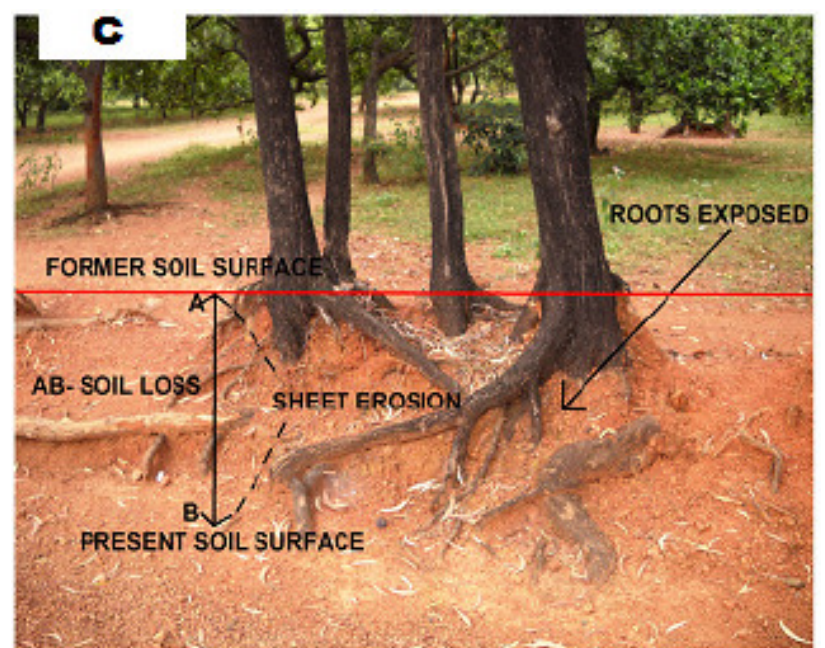

Figure 2 (a) A truncated profile of low-level laterite showing the detrital laterites occurred as hard concretions as gravels and pebbles at top and then white pallid zone overlying on the secondary weathered laterites (b) newly developed shallow gully on the bare laterites showing sediment deposition on bed and (c) evidence of sheet erosion and root exposures at Bhatina Village, Rampurhat I Block

\section{Sample Collection and Techniques}

Pedogeomorphology, proposed by Conacher and Darlymple (1977), deals with the mechanics, factors, processes and measurement of soil erosion (Gerrad, 1981). It demands the quantitative methodology incorporating statistical and mathematical equations to analyze dynamic phenomena. It is not possible to quantify all forms of water erosion within a short period; so we should go for the application of empirical models of predicting soil loss in sample locations or plots. The present investigation is carried out at different positions in the landscape of $8^{\text {th }}$ spatial ordering of landform (spatial scaleslope and flat facets) and steady time (temporal scale- short and instantaneous time over a slope segment). Topographical sheet (72 P/12/NE, 1979), District Resource Map of Birbhum district (Geological Survey of India, 2001), climatic data of Indian Meteorological Department and Irrigation and Waterways Department of West Bengal, satellite images (Landsat and IRS), numerous literatures, bulletins and reports are the supportive information in this regard. In the field session, data related to geomorphology (e.g. slope gradient) and pedology (e.g. soil sample) is 
collected and measured. Eight sample slope segments are taken along the valley-side slope of continuous gullies to estimate soil loss (fig 3 ). In the post-field session all those data are tabulated and manipulated to understand the actual ground reality. The empirical equations, soil loss equations (USLE and MMF) and data analysis are done in Microsoft Excel 2003 and the cartographic works, ranging from delineation of study area to thematic mapping (e.g. creating shape file and sub-setting of area of interest) are done in MapInfo 9.0 software.

The employed models are briefly described here for understanding the processes and functions of soil-denudation system. The USLE requires only nine parameters and three operating functions (Wischmeier and Smith, 1972, 1978).
Table 1Input parameters of Universal Soil Loss Equation

\begin{tabular}{cl} 
Parameters & Description \\
\hline $\mathrm{X}$ & mean annual rainfall in mm \\
$\mathrm{M}$ & $\begin{array}{l}\text { soil texture [ \% silt (100 - \% } \\
\text { clay) ] }\end{array}$ \\
$\mathrm{a}$ & organic matter (\%) \\
$\mathrm{b}$ & soil structure \\
$\mathrm{c}$ & soil permeability \\
$\mathrm{I}$ & slope length (metre) \\
$\mathrm{S}$ & slope angle (\%) \\
$\mathrm{C}$ & crop and vegetation factor \\
$\mathrm{P}$ & soil conservation and \\
& protection factor \\
\hline
\end{tabular}

Table 2.Operating functions in USLE

1. $\mathrm{EI}_{30}$ (Rainfall Erosivity Factor, $\left.\mathrm{R}\right)=79+0.363 \mathrm{X}$

2. $\mathrm{K}$ (Soil Erodibility Factor) $=1.2917\left[2.110^{-4} \mathrm{M}^{1.14}(12-\mathrm{a})+3.25(\mathrm{~b}-\right.$ 2) $+2.5(\mathrm{c}-3)] / 100$

3. $\quad$ LS (Topographic Factor $)=(1 / 22.13)^{\mathrm{m}}(0.065+0.045 \mathrm{~S}+0.0065 \mathrm{~S})$

The main final equation of USLE method (figure 4) of predicting annual soil loss (NBSS and LUP, 2005) is as follows:

\section{$\mathbf{A}=\mathbf{R}$ K LS C P}

Where;

$\mathbf{A}=$ soil loss per unit area (tons/ha/year),

$\mathbf{R}=$ the erosivity factor to account for the erosive power of rainfall, related to the amount and intensity of rainfall over the year (erosivity index unit,);

$\mathbf{K}=$ the soil erodibility factor to account for the soil loss rate in tones/ha erosion index unit plot which is defined as a plot of $22.1 \mathrm{~m}$ long on a $9 \%$ slope under a continuous bare cultivated fallow, it ranges from less than 0.1 for the least erodible soils to approaching 1.0 in the worst possible case;

$\mathbf{L S}=$ the topographic factor to account for the length and steepness of the slope; the longer the slope, the greater is the volume of surface runoff, the steeper the slope, the greater is its velocity, $\mathrm{LS}=1.0$ on a $9 \%$ slope, 22.1 metre long;

$\mathbf{C}=$ the cover and management to account for the effects of vegetative cover and management techniques which reduce the rate of the soil loss, so in the worst case when none are applied, $\mathrm{C}=1.0$ whereas in an ideal case when there is no loss, $\mathrm{C}$ would be zero and $\mathbf{P}=$ the support and conservation practices factor to account for the effects of soil conservation measures.

Morgan (1984) and Morgan and Finney (2001) developed a suitable erosion estimation model to incorporate more internal and external factors of soil loss, incorporating water phase of erosion and sediment phase of transportation (Morgan, 2005). This model is summarized as follows (Morgan and Duzant, 2008). 
Table 3.Input parameters to the MMF method of predicting soil loss (Morgan, 2005)

\begin{tabular}{|c|c|c|}
\hline Factor & Parameter & Description \\
\hline \multirow{3}{*}{ Rainfall } & $\mathrm{R}$ & mean annual rainfall $(\mathrm{mm})$ \\
\hline & $\mathrm{R}_{\mathrm{n}}$ & number of rain days per year \\
\hline & I & typical value for intensity of erosive rain ( $\mathrm{mm} /$ hour) \\
\hline \multirow{8}{*}{ Soil } & MS & soil moisture content at field capacity (wt $\%)$ \\
\hline & $\mathrm{BD}$ & bulk density of the top soil layer $\left(\mathrm{Mg} \mathrm{m}^{-3}\right)$ \\
\hline & EHD & effective hydrological depth of soil (m) \\
\hline & K & soil detachability index $\left(\mathrm{g} \mathrm{J}^{-1}\right)$ \\
\hline & $\mathrm{COH}$ & $\begin{array}{l}\text { cohesion of the surface soil }(\mathrm{KPa}) \text { as measured with a torvance under } \\
\text { saturated conditions }\end{array}$ \\
\hline & SD & total soil depth (m) defined as the depth of soil surface to bedrock \\
\hline & $\mathrm{W}$ & $\begin{array}{l}\text { rate of increase in soil depth by weathering at the rock-soil interface } \\
\left(\mathrm{mm} \mathrm{yr}^{-1}\right)\end{array}$ \\
\hline & V & rate of increase in effective hydrological layer $\left(\mathrm{mm} \mathrm{yr}^{-1}\right)$ \\
\hline \multirow{7}{*}{$\begin{array}{c}\text { Landform } \\
\text { and Land } \\
\text { Cover }\end{array}$} & $\mathrm{S}$ & slope steepness $\left({ }^{\circ}\right)$ \\
\hline & A & $\begin{array}{l}\text { proportion (between } 0 \text { and } 1 \text { ) of the rainfall intercepted by the } \\
\text { vegetation or crop cover }\end{array}$ \\
\hline & $\mathrm{E}_{\mathrm{t}} / \mathrm{E}_{\mathrm{o}}$ & ratio of actual $\left(\mathrm{E}_{\mathrm{t}}\right)$ to potential $\left(\mathrm{E}_{\mathrm{o}}\right)$ evapotranspiration \\
\hline & $\mathrm{C}$ & crop cover management factor; combines the $\mathrm{C}$ and P factors of USLE \\
\hline & $\mathrm{CC}$ & proportion of canopy cover (between 0 and 1 ) \\
\hline & GC & proportion of ground cover (between 0 and 1 ) \\
\hline & PH & $\begin{array}{l}\text { plant height }(\mathrm{m}) \text {, representing the height from which raindrops fall } \\
\text { from the crop or vegetation cover to the ground surface }\end{array}$ \\
\hline Time & $\mathrm{N}$ & number of consecutive years for which the model is to operate \\
\hline
\end{tabular}

Table 4.Operating Functions for MMF method (Morgan, 2005)

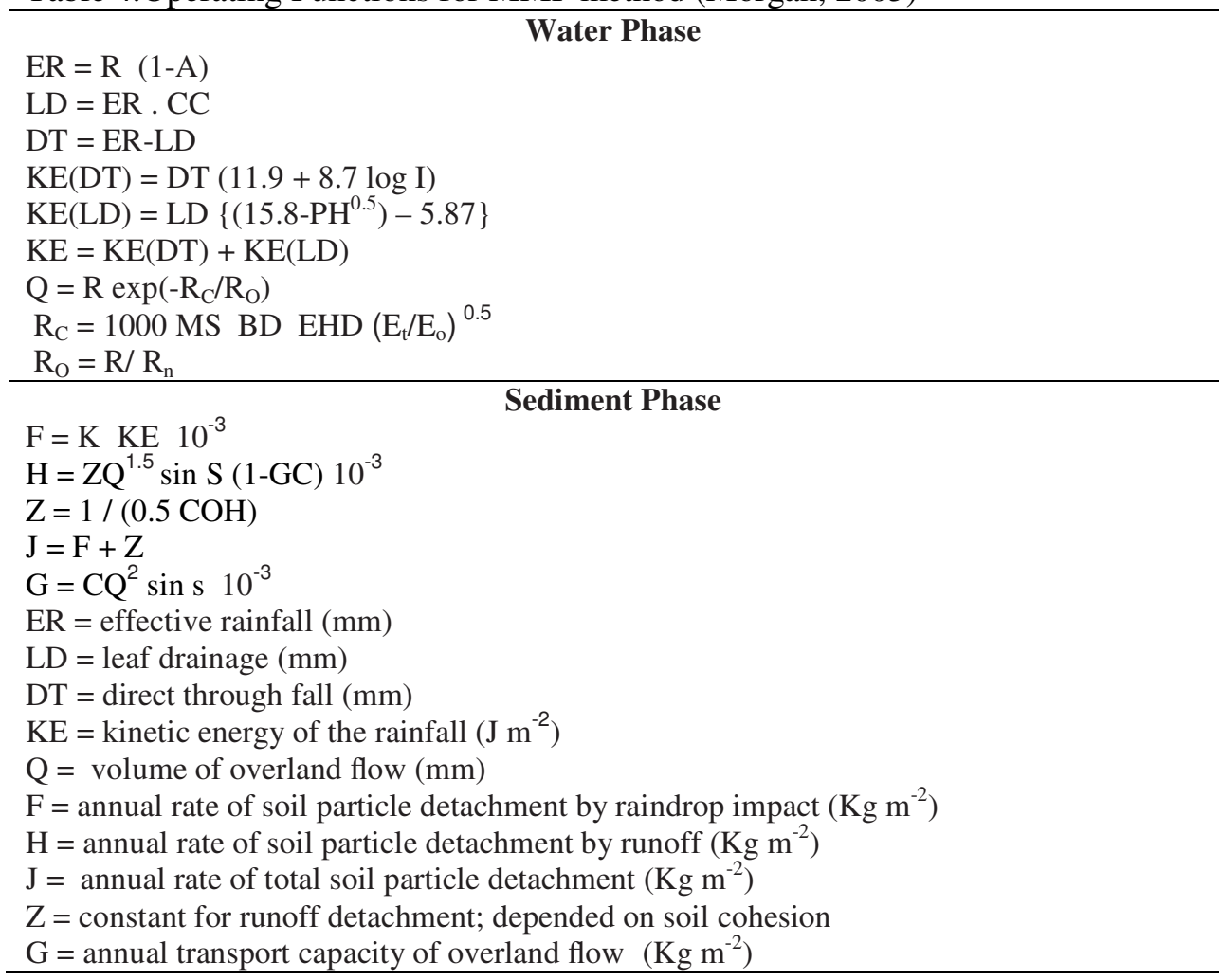




\section{Results and Discussions \\ Concise Outline of Lateritic Soil}

The local name of lateritic soil is 'Kankara' (literally gravelly) which is a reddish, loose and friable laterite soil containing ferruginous concretion and the soil is equivalence with soil series of Bhatina, Maldiha, Raspur and Jhinjharpur (Sarkar et al., 2007). Before going into the details of soil erosion, it is necessary to understand and depict the inherent characteristics of lateritic

Table 5.Significant Characteristics of Lateritic soil

\begin{tabular}{|c|c|c|}
\hline Parameters & Class Association & Remarks \\
\hline Slope of the surface & $\begin{array}{l}\text { Moderate sloping } \\
(8-15 \%)\end{array}$ & $\begin{array}{l}\text { influencing drainage, runoff, erosion and } \\
\text { land capability }\end{array}$ \\
\hline $\begin{array}{l}\text { AWC (Average Water- } \\
\text { Holding Capacity) }\end{array}$ & $\begin{array}{l}\text { very low-low }(<50 \\
\mathrm{mm} / \mathrm{m})\end{array}$ & $\begin{array}{l}\text { low moisture content and low absorption of } \\
\text { water by plants }\end{array}$ \\
\hline Soil Erosion & $\begin{array}{l}\text { moderate-severe } \\
(20-40 \mathrm{t} / \mathrm{ha} / \mathrm{y})\end{array}$ & $\begin{array}{l}\text { water erosion in monsoonal rains (sheet, rill } \\
\text { and gully erosion) }\end{array}$ \\
\hline Soil Drainage & $\begin{array}{l}\text { excessively well } \\
\text { drained }\end{array}$ & $\begin{array}{l}\text { quick removal of water from soil by surface } \\
\text { and subsurface flow }\end{array}$ \\
\hline Texture & $\begin{array}{l}\text { sandy clay loam, } \\
\text { sandy loam and } \\
\text { loamy sand }\end{array}$ & $\begin{array}{l}\text { weak soil structure, low cohesion, low AWC, } \\
\text { dominance of sand }\end{array}$ \\
\hline Depth & $\begin{array}{l}\text { very shallow- } \\
\text { shallow }(10-50 \mathrm{~cm})\end{array}$ & $\begin{array}{l}\text { low root depth, not favourable for crops and } \\
\text { chance more soil loss }\end{array}$ \\
\hline${ }_{\mathrm{p}} \mathrm{H}$ & $\begin{array}{l}\text { strongly acidic (5.1- } \\
5.5)\end{array}$ & $\begin{array}{l}\text { not favour availability of minerals and plant } \\
\text { nutrients }\end{array}$ \\
\hline Organic Carbon & low $(0.5-1.3 \%)$ & $\begin{array}{l}\text { weak soil aggregation, low water retention, } \\
\text { low biological activity and increase } \\
\text { erodibility }\end{array}$ \\
\hline Land Capability sub-class & VIes & $\begin{array}{l}\text { very shallow root depth, gravelliness and } \\
\text { stoniness, prolonged dryness, severe } \\
\text { erosional problem }\end{array}$ \\
\hline Land Irrigability sub-class & 4 st & $\begin{array}{l}\text { gravelly soil, medium texture, unfavourable } \\
\text { topography, marginal land for sustained use } \\
\text { under irrigation }\end{array}$ \\
\hline Crop Suitability and Land Use & $\begin{array}{l}\text { maize in Summer, } \\
\text { horse gram in } \\
\text { Winter }\end{array}$ & $\begin{array}{l}\text { plantation of low water requirement tree, } \\
\text { forest, orchards, control grazing }\end{array}$ \\
\hline
\end{tabular}

soil of this area which are more responsible for high soil erodibility, severe water erosion, infertility and barrenness in these geo-climatic conditions. Soils of the study area are interpreted or evaluated on the basis of slope, Available Water Capacity (AWC), soil erosion, soil drainage, soil texture, soil depth, $\mathrm{pH}$, organic carbon, land capability, land irrigability and crop suitability by NBSS and LUP (2007).

Source: NBSS publ. No. 130, NBSS and LUP (ICAR), 2007

\section{Modelling Soil Erosion}

Soil Erosion is two-phase process consisting of the detachment of individual particles from the soil mass and their transport by erosive agents such as running water, when sufficient energy is no longer available to transport the particles a third phase, deposition occur' (Morgan, 1986). Detachment and transportation ability increase substantially when overland flow is concentrated into thin thread like channels forming grooves called rills, microchannels with typical dimensions of
50-300 mm wide and up to $300 \mathrm{~mm}$ deep (Morgan, 2005). Rills are preceded by small undulations formed on the surface of the ground by the impact of raindrops during heavy rains. As the water continues to concentrate and acquires additional energy for scouring, these grooves (rills) become deeper and broader and eventually some of them develop into steep-sided ephemera gullies (Morgan, 1986; Singh and Dubey, 2002).

The empirical model is based on identifying statistically significant 
relationships between assumed important variables where a reasonable database exists. Most of the models of soil erosion studies are of empirical 'grey-box type' which is based on defining the most important factors and through the use of observation, measurement, experiment and statistically techniques, relating them to soil loss (Morgan, 1986).

The 'time scale' is important here to assess annual rate of soil loss. The detailed requirement for modelling erosion (USLE and MMF) over a gully-catchment is fulfilled by selecting short length of hillslope (from water divide to gully base) which is the 'spatial scale' (fig 3). Here the main influencing factors of soil loss are climate (macro factor), relief-slope (meso factor), plant cover and soil characteristics (micro factor).

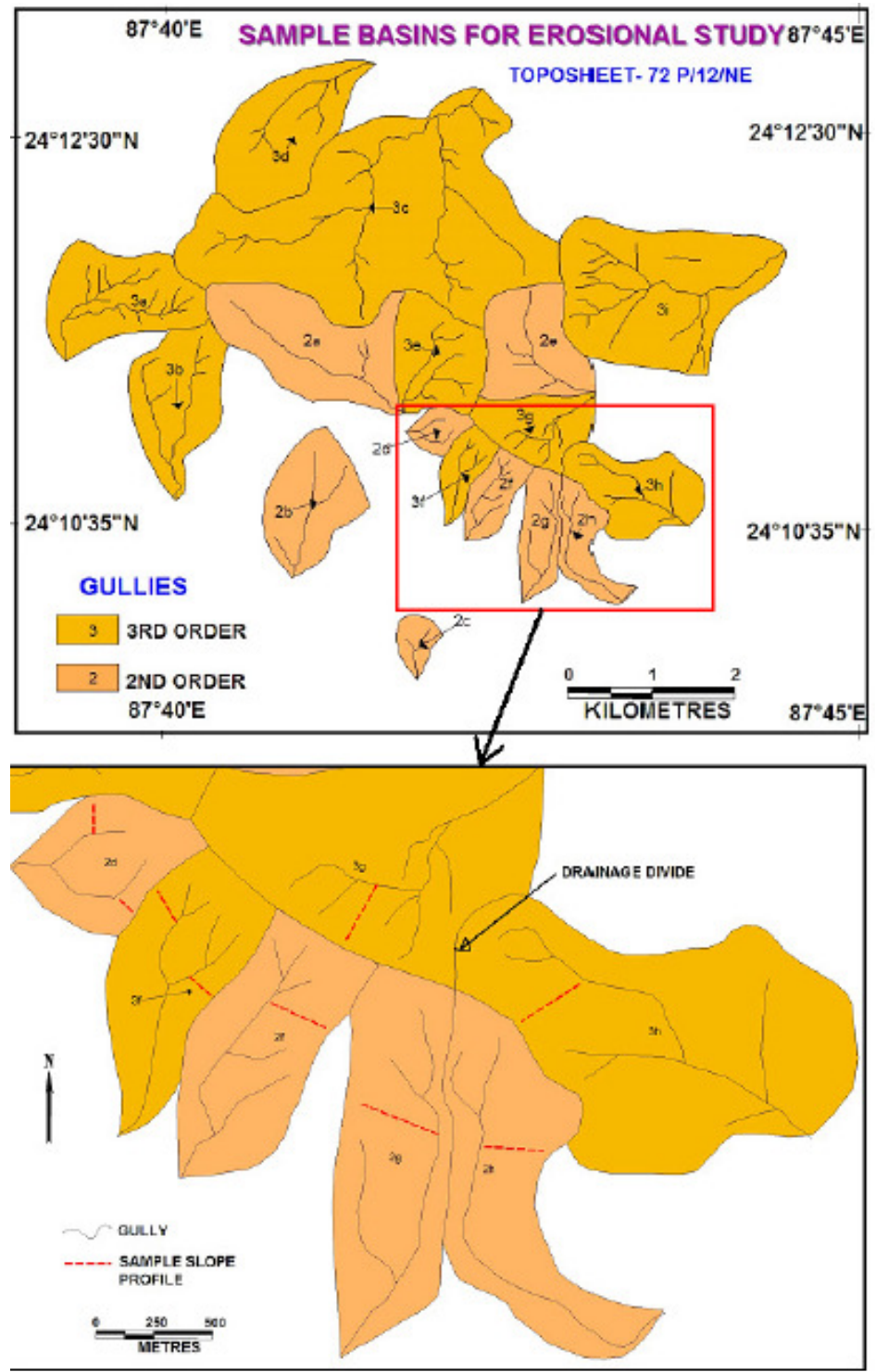

Figure 3: Samples of gully-catchments and selected slope facets taking for analysis

USLE Model of Predicting Annual Loss of Lateritic Soil

First of all, Zingg (1940) had published an equation relating soil loss rate to length and percentage of slope (Wischmeier and Smith, 1978). Further developments led to the addition of a climatic factor based on the maximum 30-minute rainfall total with a twoyear return period, a crop factor, to take account of the protection-effectiveness of different crops, the climatic factor to the rainfall erosivity index $(\mathrm{R})$ ultimately yielded 
the Universal Soil Loss Equation (Wischmeier and Smith, 1972). The essence of the USLE is to isolate each variable and reduce its effect to a number so that when the numbers are multiplied together the answer is the amount of soil loss (Hudson, 1984). When the equation is used for the selection of suitable farming, land use practices or land cover the value of A (annual soil loss) is the soil-loss tolerance, the value is the greatest amount of erosion which can be tolerated without productivity declines (Hudson, 1984).
To calculate annual rate of soil loss we have taken into consideration of mean annual rainfall of $1437 \mathrm{~mm}$, mostly Bhatina-RaspurJhinjharpur soil series association, slope facets (having glimpses of rills and gullies) and barren waste land with thin grass cover upon crusted lateritic soil. From the analysis we have found that annual predicted loss of lateritic soil (using USLE) ranges from 0.8 to $4.11 \mathrm{~kg} / \mathrm{m}^{2} /$ year (table 6,7 and 8 ).

Table 6 Soil structure code and permeability code (after Wischmeier, Johnson and Cross, 1971)

\begin{tabular}{llll}
\hline \multicolumn{1}{c}{ Soil structure (b) } & & \multicolumn{2}{c}{ Soil Permeability (c) } \\
\hline Very fine granular & 1 & very slow & 6 \\
Fine granular & 2 & slow & 5 \\
Coarse granular & 3 & slow to moderate & 4 \\
Blocky, platy or massive & 4 & moderate & 3 \\
& & moderate to rapid & 2 \\
& & rapid & 1 \\
\hline
\end{tabular}

Table 7 Estimating input soil parameters of USLE for sample sites

\begin{tabular}{|c|c|c|c|c|c|c|c|c|c|}
\hline $\begin{array}{l}\text { Sample } \\
\text { site }\end{array}$ & $\begin{array}{l}\text { Latitude } \\
\text { (N) }\end{array}$ & $\begin{array}{l}\text { Longitude } \\
\text { (E) }\end{array}$ & $\begin{array}{l}\text { sand } \\
\%\end{array}$ & $\begin{array}{l}\text { silt } \\
\%\end{array}$ & $\underset{\%}{\text { clay }}$ & $\begin{array}{c}\text { Organic } \\
\text { Matter } \\
(\%)\end{array}$ & $\begin{array}{c}\text { Soil } \\
\text { Texture }\end{array}$ & $\begin{array}{l}\text { Structure } \\
\text { code }\end{array}$ & $\begin{array}{l}\text { Permeability } \\
\text { code }\end{array}$ \\
\hline 1 & $24^{\circ} 10^{\prime} 40^{\prime \prime}$ & $87^{\circ} 42^{\prime} 40^{\prime \prime}$ & 49.8 & 27.6 & 22.6 & 0.25 & $\begin{array}{l}\text { clay } \\
\text { loam }\end{array}$ & 4 & 3 \\
\hline 2 & $24^{\circ} 11^{\prime} 06^{\prime \prime}$ & $87^{\circ} 42^{\prime} 40^{\prime \prime}$ & 65.3 & 24.6 & 10.1 & 0.6 & $\begin{array}{l}\text { sandy } \\
\text { loam }\end{array}$ & 4 & 2 \\
\hline 3 & $24^{\circ} 10^{\prime} 57^{\prime \prime}$ & $87^{\circ} 42^{\prime} 49^{\prime \prime}$ & 64 & 22.4 & 13.6 & 0.68 & $\begin{array}{l}\text { sandy } \\
\text { loam } \\
\text { sandy }\end{array}$ & 4 & 2 \\
\hline 4 & $24^{\circ} 11^{\prime} 23^{\prime \prime}$ & $87^{\circ} 42^{\prime} 40^{\prime \prime}$ & 50.1 & 27.3 & 22.6 & 0.25 & $\begin{array}{l}\text { clay } \\
\text { loam } \\
\text { sandy }\end{array}$ & 3 & 3 \\
\hline 5 & $24^{\circ} 11^{\prime 2} 24^{\prime \prime}$ & $87^{\circ} 42^{\prime} 06^{\prime \prime}$ & 52.6 & 28.3 & 19.1 & 0.21 & $\begin{array}{l}\text { clay } \\
\text { loam }\end{array}$ & 4 & 2 \\
\hline 6 & $24^{\circ} 11^{\prime} 51^{\prime \prime}$ & $87^{\circ} 42^{\prime} 41^{\prime \prime}$ & 70.2 & 19.1 & 10.7 & 0.57 & $\begin{array}{l}\text { sandy } \\
\text { loam }\end{array}$ & 3 & 3 \\
\hline 7 & $24^{\circ} 11^{\prime} 46^{\prime \prime}$ & $87^{\circ} 42^{\prime} 16^{\prime \prime}$ & 48.3 & 22.6 & 29.1 & 1.6 & $\begin{array}{l}\text { clay } \\
\text { loam }\end{array}$ & 3 & 4 \\
\hline 8 & $24^{\circ} 10^{\prime} 43^{\prime \prime}$ & $87^{\circ} 42^{\prime} 21^{\prime \prime}$ & 49.1 & 28.3 & 22.6 & 1.3 & $\begin{array}{l}\text { clay } \\
\text { loam }\end{array}$ & 4 & 3 \\
\hline
\end{tabular}


Table 8.Estimation of predicted soil loss (tons/ha/year) from eight sample sites

\begin{tabular}{cccccccccc}
\hline $\begin{array}{c}\text { Sample } \\
\text { Site }\end{array}$ & $\begin{array}{c}\text { Slope } \\
\text { Length } \\
(\mathbf{m})\end{array}$ & $\begin{array}{c}\text { Slope } \\
\text { angle } \\
(\mathbf{d e g r e e})\end{array}$ & $\mathbf{R}$ & $\mathbf{K}$ & $\mathbf{L S}$ & $\mathbf{C}$ & $\mathbf{P}$ & $\begin{array}{c}\mathbf{A}(\mathbf{t} / \mathbf{h a} / \\
\mathbf{y e a r})\end{array}$ & $\begin{array}{c}\mathbf{A}(\mathbf{k g} / \\
\left.\mathbf{m}^{2} / \mathbf{y e a r}\right)\end{array}$ \\
\hline 1 & 37 & 2.8 & 600 & 0.28 & 0.29 & 0.5 & 1 & 24.36 & 2.43 \\
2 & 20 & 4.5 & 600 & 0.31 & 0.43 & 0.65 & 0.7 & 36.4 & 3.64 \\
3 & 29 & 4 & 600 & 0.22 & 0.43 & 0.5 & 1 & 28.38 & 2.83 \\
4 & 38 & 2.2 & 600 & 0.22 & 0.39 & 0.45 & 0.7 & 16.21 & 1.62 \\
5 & 19 & 3.2 & 600 & 0.26 & 0.48 & 0.55 & 1 & 41.18 & 4.11 \\
6 & 86 & 2.3 & 600 & 0.19 & 0.47 & 0.4 & 0.7 & 15 & 1.5 \\
7 & 23 & 2.7 & 600 & 0.2 & 0.24 & 0.4 & 0.7 & 8.06 & 0.8 \\
8 & 17 & 3.3 & 600 & 0.27 & 0.52 & 0.45 & 0.7 & 26.53 & 2.65 \\
\hline
\end{tabular}

MMF Method of Predicting Annual Soil Loss

Morgan et al. (1984) developed a suitable model to predict annual soil loss from fieldsized areas on hillslopes which, while endeavouring to retain the simplicity of USLE, encompassed some recent advances in understanding of erosion processes (Morgan, 1986; Morgan, 2005). The approach was revised by Morgan in 2001. The model was complied and redefined by bringing together the results of research by geomorphologists and agricultural engineers. The model separates the soil erosion processes into a 'water phase' and a 'sediment phase' (table 4). Morgan considers soil erosion to result from the detachment of soil particles by raindrop impact and the transport of those particles by overland flow.

The water phase comprises nine operating functions and includes rainfall energy (summation of kinetic energy of direct through fall and leaf drainage) and volume of overland flow. The basic input parameters (table 3) to this phase is mean annual rainfall, rainy days per year, rainfall interception by vegetation, canopy cover, ground slope, soil moisture storage capacity, evapotranspiration etc. Here empirical equations of Carson and Krikby (1972), Withers and Vipond (1974), and Krikby (1976) are used.

The sediment phase comprises three predictive equations, one for the rate of particle detachment by rainsplash, one for the rate of particle detachment by runoff and one for the transport capacity of overland flow (Morgan, 2005).

The model compares the predictions of detachment by rainsplash and the transport capacity of the runoff and assigns the lower of the two values as the annual rate of soil loss, thereby denoting whether detachment or transport is the limiting factor (Morgan, 1986). Again to calculate annual soil loss we have taken into consideration of mean annual rainfall of $1437 \mathrm{~mm}$, mostly Bhatina-RaspurJhinjharpur soil series association, slope facets (having glimpses of rills and gullies) and barren waste land with thin grass cover upon crusted lateritic soil. From the analysis we have found that annual predicted loss of lateritic soil (using MMF method, 2001) ranges from 1.17 to $17 \mathrm{~kg} / \mathrm{m}^{2} /$ year (table 9,10 and 11). 
Ethiopian Journal of Environmental Studies and Management EJESM Vol. 5 no.4 (Suppl.2) 2012

Table 9 Estimating input parameters to MMF method

\begin{tabular}{|c|c|c|c|c|c|c|c|c|c|c|c|c|c|}
\hline $\begin{array}{l}\text { sample } \\
\text { site }\end{array}$ & $\sin S$ & $\begin{array}{c}\text { Soil } \\
\text { Texture }\end{array}$ & MS & BD & EHD & $\mathbf{K}$ & $\mathrm{COH}$ & $\mathbf{A}$ & $\mathbf{E}_{\mathbf{t}} / \mathbf{E}_{\mathbf{o}}$ & $\mathrm{CC}$ & GC & $\mathbf{P H}^{1}$ & C \\
\hline 1 & 0.048 & $\begin{array}{l}\text { clay } \\
\text { loam }\end{array}$ & 0.4 & 1.3 & 0.05 & 0.7 & 10 & 0 & 0.05 & 0.1 & 0.2 & \multirow{8}{*}{0} & 1 \\
\hline 2 & 0.078 & $\begin{array}{l}\text { sandy } \\
\text { loam }\end{array}$ & 0.28 & 1.2 & 0.05 & 0.7 & 2 & 0 & 0.05 & 0.1 & 0.2 & & 1 \\
\hline 3 & 0.069 & $\begin{array}{l}\text { sandy } \\
\text { loam }\end{array}$ & 0.28 & 1.2 & 0.05 & 0.7 & 2 & 0 & 0.05 & 0.2 & 0.2 & & 1 \\
\hline 4 & 0.038 & $\begin{array}{l}\text { sandy } \\
\text { clay } \\
\text { loam }\end{array}$ & 0.28 & 1.2 & 0.09 & 0.1 & 3 & 0.25 & 0.8 & 0.3 & 0.3 & & 0.1 \\
\hline 5 & 0.055 & $\begin{array}{l}\text { sandy } \\
\text { clay } \\
\text { loam }\end{array}$ & 0.28 & 1.2 & 0.09 & 0.1 & 3 & 0.25 & 0.8 & 0.3 & 0.3 & & 0.1 \\
\hline 6 & 0.040 & $\begin{array}{l}\text { sandy } \\
\text { loam }\end{array}$ & 0.28 & 1.2 & 0.05 & 0.7 & 2 & 0 & 0.05 & 0.2 & 0.1 & & 1 \\
\hline 7 & 0.047 & $\begin{array}{l}\text { clay } \\
\text { loam }\end{array}$ & 0.4 & 1.3 & 0.05 & 0.7 & 10 & 0 & 0.05 & 0.2 & 0.2 & & 1 \\
\hline 8 & 0.057 & $\begin{array}{l}\text { clay } \\
\text { loam }\end{array}$ & 0.4 & 1.3 & 0.05 & 0.7 & 10 & 0 & 0.05 & 0.2 & 0.3 & & 1 \\
\hline
\end{tabular}

Note: ${ }^{1} \mathrm{PH}$ - plant height $(\mathrm{m})$ is negligible (becomes zero) here because main plants are thin grass; typical values of parameters are summarized by Morgan (2005)

Table 10 Estimating water phase of MMF method of predicting soil loss

\begin{tabular}{cccccccccc}
\hline $\begin{array}{c}\text { Sample } \\
\text { site }\end{array}$ & $\begin{array}{c}\mathbf{E R} \\
(\mathbf{m m})\end{array}$ & $\begin{array}{c}\mathbf{L D} \\
(\mathbf{m m})\end{array}$ & $\begin{array}{c}\mathbf{D T} \\
(\mathbf{m m})\end{array}$ & $\begin{array}{c}\mathbf{K E}(\mathbf{D T})^{1} \\
\left(\mathbf{J ~ m}^{-2}\right)\end{array}$ & $\begin{array}{c}\mathbf{K E}(\mathbf{L D}) \\
\left(\mathbf{J ~ m}^{-2}\right)\end{array}$ & $\begin{array}{c}\mathbf{K E ~}_{\mathbf{2}} \mathbf{( J \mathbf { ~ m }} \\
-\end{array}$ & $\begin{array}{c}\mathbf{R}_{\mathbf{C}} \\
(\mathbf{m m})\end{array}$ & $\begin{array}{c}\mathbf{R}_{\mathbf{O}} \\
(\mathbf{m m})\end{array}$ & $\mathbf{Q}(\mathbf{m m})$ \\
\hline 1 & 1437 & 215.55 & 1221.45 & 29483.71 & 2140.412 & 31624.13 & 22.38 & 251.12 \\
2 & 1437 & 143.7 & 1293.3 & 31218.05 & 1426.941 & 32644.99 & 14.46 & 465.57 \\
3 & 1437 & 287.4 & 1149.6 & 27749.38 & 2853.882 & 30603.26 & 14.46 & 465.57 \\
4 & 1077.25 & 215.45 & 861.8 & 20802.38 & 2139.419 & 22941.80 & 27.04 & 12.83 & 174.64 \\
5 & 1077.25 & 215.45 & 861.8 & 20802.38 & 2139.419 & 22941.80 & 27.04 & 174.64 \\
6 & 1437 & 287.4 & 1149.6 & 27749.38 & 2853.882 & 30603.26 & 14.46 & 465.57 \\
7 & 1437 & 287.4 & 1149.6 & 27749.38 & 2853.882 & 30603.26 & 22.38 & 251.12 \\
8 & 1437 & 287.4 & 1149.6 & 27749.38 & 2853.882 & 30603.26 & 22.38 & 251.12 \\
\hline
\end{tabular}

Note: ${ }^{1}$ Maximum erosive intensity of monsoonal rains (I) is $25.51 \mathrm{~mm} \mathrm{hr}^{-1}$ in the study area (after, Water Resource and its Quality in West Bengal, A State of Environmental Report, WBPCB, 2009).

Table 11.Estimating sediment phase and annual soil loss to MMF method of predicting soil loss and comparing with results of USLE

\begin{tabular}{|c|c|c|c|c|c|c|c|c|}
\hline $\begin{array}{c}\text { Sample } \\
\text { slope }\end{array}$ & $\begin{array}{c}\mathbf{F} \\
(\mathrm{Kg} \\
\left.\mathbf{m}^{-2}\right)\end{array}$ & $\mathbf{Z}$ & $\begin{array}{c}\mathbf{H} \\
(\mathbf{K g} \\
\left.\mathbf{m}^{-2}\right)\end{array}$ & $\begin{array}{c}\mathbf{J}= \\
(\mathbf{F}+\mathbf{H}) \\
\left(\underset{2}{\mathbf{K g}} \mathbf{~ m}^{-}\right.\end{array}$ & $\left(\begin{array}{l}\mathbf{K g ~ m}^{-} \\
\mathrm{m}^{-}\end{array}\right.$ & $\begin{array}{c}\text { (MMF) } \\
\text { Annual } \\
\text { soil } \\
\text { loss }(\mathrm{Kg} \\
\left.\mathbf{m}^{-2} / \text { year }\right)\end{array}$ & $\begin{array}{c}\text { (USLE) } \\
\text { A (kg/ } \\
\left.\text { m }^{2} / \text { year }\right)\end{array}$ & $\begin{array}{l}\text { MMF/ } \\
\text { USLE }\end{array}$ \\
\hline 1 & 22.1 & 0.05 & 0.008 & 22.14 & 3.08 & 3.08 & 2.43 & 1.26 \\
\hline 2 & 22.9 & 0.25 & 0.158 & 23 & 17 & 17.00 & 3.64 & 4.67 \\
\hline 3 & 21.4 & 0.25 & 0.140 & 21.56 & 15.12 & 15.12 & 2.83 & 5.34 \\
\hline 4 & 2.3 & 0.17 & 0.011 & 2.31 & 1.17 & 1.17 & 1.62 & 0.72 \\
\hline 5 & 2.3 & 0.17 & 0.015 & 2.31 & 1.7 & 1.70 & 4.11 & 0.41 \\
\hline 6 & 21.4 & 0.25 & 0.091 & 21.51 & 8.69 & 8.69 & 1.50 & 5.79 \\
\hline 7 & 21.4 & 0.05 & 0.008 & 21.42 & 2.97 & 2.97 & 0.80 & 3.71 \\
\hline 8 & 21.4 & 0.05 & 0.008 & 21.42 & 3.63 & 3.63 & 2.65 & 1.36 \\
\hline
\end{tabular}




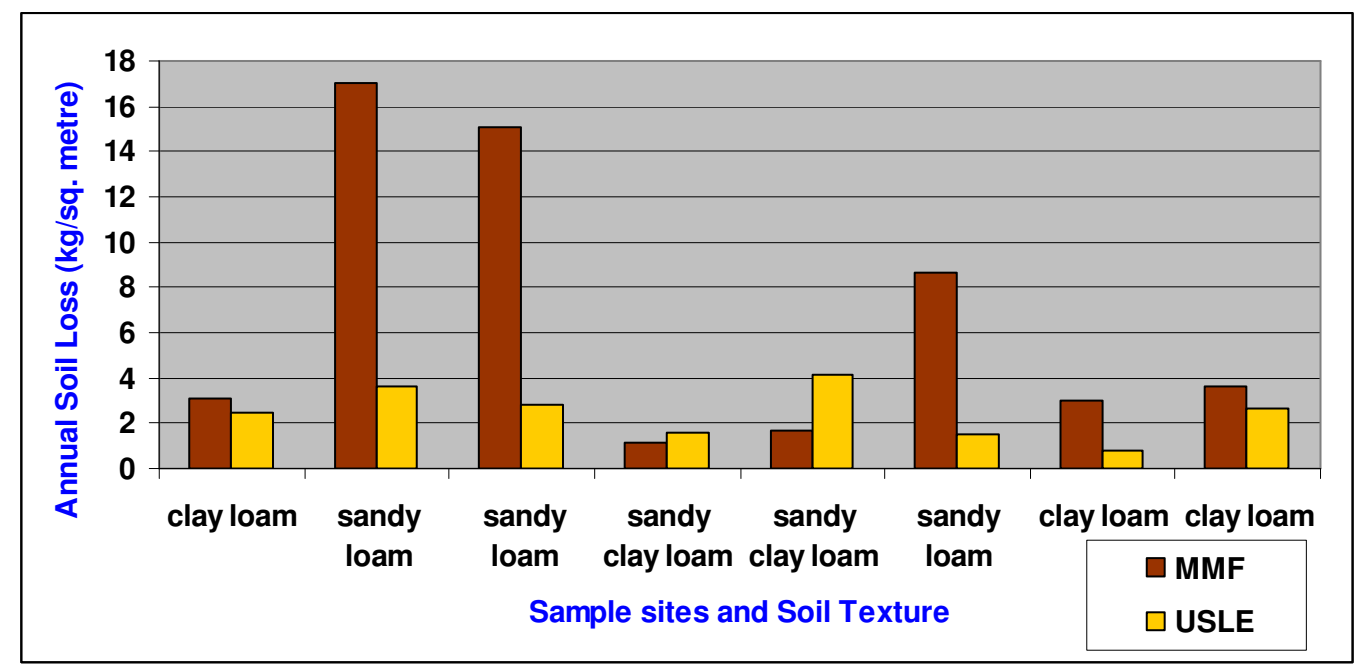

Figure 4 Comparing annual soil loss of sample sites using MMF and USLE method

\section{Conclusion}

There is significant difference in between the results of MMF and USLE and the study reveals that in comparison to USLE, employing MMF method we have obtained high value of annual soil loss (table 11 and figure 4). Sandy loam textured soils are more prone to erosion in MMF method but in USLE most of the soils exhibit equal magnitude of erosion but less than the previous method.

The results of USLE show little variation in different segments due to low variability of the factors as in such model in a micro region, range of the variables are low except length of slope and the conservation practices. So, the high value or low values is the result of length of slope, coverage and soil erodibility. Apart from length, the range of $\mathrm{K}$ and $\mathrm{C}$ in small region is also low.

The complexity of parameters interlinking in a cause-effect relationships through MMF method always reinforce soil loss more systematically as detachment of soil subsequently comes under overland flow. To reflect such intricate relationship, the model uses twelve operating functions for which nineteen input parameters are required. Such an analysis becomes critical in a region where the parameters which are expressed through other functions, have variability in nature. But this area has least crop coverage and lesser extent of slope variation. So the factors like Q, ER, LD, CC, GC etc. are all show lesser variation and can be measured correctly. But the fluctuation of the result is affected by the

sine function of the slope equation. Therefore, a relatively higher slope of $7^{\circ}$ to $8^{\circ}$ may lead to four to five times soil erosion but in this region the slope is only $1^{\circ}$ to $2^{\circ}$. There are some unexplained internal and external variables in soil erosion processes and it has aggravated the variations of soil loss rate in the same sample segments. The prime research gap is the identification and accurate estimation of the internal factors of lateritic soils which enhance the soil erodibility.

\section{References}

Bagchi, K.N. and Mukherjee, K.N. (1983), Diagnostic Survey of West Bengal. University of Calcutta: Calcutta

Cooke, R. U. and Doornkamp, J. C. (1987), Geomorphology in Environmental Management. Clarendon Press: Oxford

Gerrard, A. J. (1981), Soils and Landforms: An Integration of Geomorphology and Pedology. George Allen and Unwin: London Hudson, N. (1984). Soil Conservation. English Language Book Society: London

Hundy, A. and Banerjee, S. (1967), Geology and Mineral Resources of West Bengal. Vol. 97, Memoirs of the GSI: Delhi

Jha, V.C. and Kapat, S. (2003), Assessment of Soil Erosion and Degraded Land: A Case Study of Dumka Subdivision, Jharkhand. In V.C. Jha (Ed.), Land Degradation and Desertification (pp. 156-178). Jaipur: Rawat Publications. 
Jha, V.C. and Kapat, S. (2003), Gully Erosion and its Implications on Land Use: A Case Study of Dumka Block, Dumka District, Jharkhand. In V.C. Jha (Ed.), Land Degradation and Desertification (pp. 156178). Jaipur: Rawat Publications.

Jha, V.C. and Kapat., S. (2009), Rill and Gully Erosion Risk of Lateritic Terrain in SouthWestern Birbhum District, West Bengal, India. Sociedade \& Natureza, Uberlândia, 21 (2): 141-158, ago. 2009

Kale, V.S., Joshi, V. and Kelkar, N. (1994), Morphology and Origin of Valley-Side Gullies on Colluvium, Western Upland Maharashtra. K.R. Dikshit et al. (Ed.), India: geomorphological Diversity (pp. 451-468). Jaipur: Rawat Publications

McFarlane, M. J. (1976), Laterite and Landscape. Academic Press: London

Morgan, R. P. C. (1986), Soil Erosion and Conservation. Longman Scientific and Technical: Harlow

Morgan, R. P. C. (2005), Soil Erosion and Conservation ( $3^{\text {rd }}$ edition). Blackwell Publishing: Malden

Morgan, R.P.C. and Duzant, J.H. (2008), Modified MMF (Morgan-Morgan-Finney) model for evaluating effects of crops and vegetation cover on soil erosion. Earth Surface Processes and Landforms, Wiley InterScience, 32, 90-106

Raychaudhuri, S.P. (1980), The Occurrence, Distribution, Classification and Management of Laterite and Lateritic Soils. Journee Georges Aubert, Vol. XVIII, No.3-4, 249-252. Retrieved from http://horizon.documentation.ird.fr/exl_doc/pl eins_texts/..../1423.pdf
Sarkar, D., Nayak, D.C., Dutta, D. and Dhyani, B.L. (2005), Soil Erosion of West Bengal,.National Bureau of Soil Survey and Land Use Planning, NBSS Publ. 117, Nagpur Sarkar, D., Nayak, D.C., Dutta, D. and Gajbhiye, K.S. (2007), Optimizing Land Use of Birbhum District (West Bengal) Soil Resource Assessment. National Bureau of Soil Survey and Land Use Planning, NBSS Publ. 130, Nagpur

Sen, J., Sen, S. and Bandyopadhyay, S. (2004), Geomorphological Investigation of Badlands: A Case Study at Garhbeta, West Medinipur District, West Bengal, India. In S. Singh et al. (Ed.), Geomorphology and Environment (pp. 195-203). Kolkata: acb Publications

Sharma, H.S. (1970), Genesis of Ravines of the Lower Chambal Valley, India. In S.P. Chatterjee \& S.P. Das Gupta (Ed.), Selected papers Vol.1 Physical Geography, $21^{\text {st }}$ International Geographical Congress (pp.114118). Calcutta: National Committee for Geography

Singh, S. and Dubey, A. (2002), Gully Erosion and Management: Methods and Application.

New Academic Publishers: New Delhi

Wischmeir, W. H. and Smith, D.D. (1972), Predicting Rainfall-Erosion Losses from Cropland and East of the Rocky Mountains. USDA, Agriculture Handbook No. 282, Washington

Wischmeir, W. H. and Smith, D.D. (1978), Predicting Rainfall-Erosion Losses-A Guide to Conservation Planning. USDA, Agriculture Handbook No. 537, Washington

Young, A. (1976), Tropical Soils and Soil Survey. Cambridge: Cambridge University Press 